\title{
HUBUNGAN KEKERABATAN BAHASA REJANG, SERAWAI, DAN PASEMAH DENGAN MENGGUNAKAN TEKNIK LEKSIKOSTATISTIK
}

\author{
N afri Yanti \\ Prodi Pendidikan Bahasa dan Sastra Indonesia \\ Fakultas Keguruan dan IImu Pendidikan Universitas Bengkulu \\ Pos-el: nafri_yanti@yahoo.com
}

\begin{abstract}
A bstrak
Tujuan penelitian ini adalah untuk melihat hubungan kekerabatan antara Bahasa Rejang, Serawai dan Pasemah. Ketiga bahasa ini dipilih karena merupakan bahasa daerah mayoritas yang digunakan masyarakat Provinsi Bengkulu. Metode penelitian yang digunakan adalah metode kuantitatif dengan teknik leksikostatistik yaitu suatu teknik untuk mengkaji bahasa dengan melakukan pengelompokan data secara statistik. Pengelompokan dilakukan berdasarkan persamaan dan perbedaan suatu bahasa dengan bahasa yang lain untuk mengetahui hubungan kekerabatan bahasa tersebut. Data diperoleh berdasarkan hasil wawancara kepada penutur asli tiap bahasa tersebut. Dari hasil penelitian diketahui bahwa waktu pisah bahasa Serawai-Rejang yakni antara 1327 1138 tahun yang lalu, Bahasa Serawai-Pasemah yakni antara 455 - 347 tahun yang lalu sedangkan waktu pisah Bahasa Rejang-Pasemah yakni antara 1402 - 1188tahun yang lalu. Hal ini menunjukan bahwa ketiga bahasa tersebut masih dalam satu bahasa karena waktu pisah masih berkisar antara 0-5 abad. Jika dilihat persentase kata kerabat dapat kita ketahui bahwa kekerabatan bahasa SerawaiRejang 58\%. Serawai-Pasemah 84\% sedangkan bahasa Rejang-Pasemah 57\% yang artinya, bahwa Bahasa Serawai-Rejang dan Rejang- Pasemah merupakan satu bahasa (language), sedangkan bahasa Serawai-Pasemah merupakan Keluarga (family) karena persentasekata kerabat $84 \%$.
\end{abstract}

Kata kunci: Leksikostatistik, Rejang, Serawai, Pasemah.

\begin{abstract}
The purpose of this study is to see the relationship between Rejang, Serawai and Pasemah language. These threelanguages werechosen because it is the majority area languageused by the people of Bengkulu Province. Theresearch method used is quantitativemethod with lexicostatistics techniquethat is a techniqueto study the language by doing grouping data statistically. Grouping is donebased on thesimilarities and differences of a language with another language to know the kinship relationship of the language. The data were obtained based on interviews to native speakers of each language. From the result of the research, it is known that Serawai-R ejang split timeis between 1327 - 1138 years ago, Serawai-P asemah Language is between 455 - 347 years ago while the time of split of Rejang-Pasemah language is between $1402-1188$ years ago. This shows that thethreelanguages arestill in onelanguage becausethe time of separation is still ranged from $0-5$ century. If you see the percentage of the word relatives we can know that the kinship language Serawai-R ejang $58 \%$. Serawai-Pasemah $84 \%$ whileR ejang-P asemah languageis $57 \%$ which means that Serawai-Rejang and RejangPasemah Language is onelanguage, while Serawai-P asemah is Family because the percentage of the word is $84 \%$ relative.
\end{abstract}

Keyw ords: Leksikostatistik, Rejang, Serawai, Pasemah 


\section{PENDAHULUAN}

Pada awal berdirinya, Provinsi Bengkulu hanya terdiri dari 3 kabupaten dan 1 kotamadya. Namun seiring perkembangan era otonomi daerah, Provinsi Bengkulu telah melakukan beberapa pemekaran wilayah. Saat ini, Provinsi Bengkulu telah terdiri dari sembilan kabupaten dan satu kota, yakni: (1) kabupaten Rejang Lebong (RL), (2) kabupaten Lebong (eks pemekaran kabupaten RL), (3) Kabupaten Kepahiang (eks pemekaran kabupaten RL), (4) kabupaten Bengkulu Utara (BU), (5) kabupaten Muko-muko (eks pemekaran kabupaten BU), (6) kabupaten Bengkulu Tengah (eks pemekaran kabupaten BU), (7) kabupaten Bengkulu Selatan (BS), (8) kabupaten Seluma (eks pemekaran kabupaten BS), (9) kabupaten Kaur (eks pemekaran kabupaten BS), dan (10) kota Bengkulu. Berdasarkan hasil pengamatan dan penelusuran pada situs wikipedia Provinsi Bengkulu diketahui bahwa kelompok etnik yang hidup serta berkembang di kesepuluh daerah di Provinsi Bengkulu dapat dibedakan atas suku bangsa atau bahasa sebagai berikut:

- $\quad$ Suku Rejang (menempati wilayah kabupaten Rejang Lebong, kabupaten Lebong, kabupaten Kepahiang, serta sebagian kabupaten Bengkulu Utara dan kabupaten Bengkulu Tengah)

- $\quad$ Suku Serawai (menempati wilayah kabupaten Bengkulu Selatan, kabupaten Seluma, dan sebagian kotamadya Bengkulu)

- $\quad$ Suku Lembak (menempati wilayah kabupaten Bengkulu Tengah dan sebagian kabupaten Rejang Lebong)

- $\quad$ Suku Pekal (menempati sebagian wilayah kabupaten Bengkulu Utara dan MukoMuko)

- $\quad$ Suku Muko-muko (menempati wilayah kabupaten Muko-muko)

- $\quad$ Suku Enggano (menempati pulau Enggano/ masuk dalam wilayah kabupaten Bengkulu Utara)

- $\quad$ Suku Mulak Bintuhan (menempati wilayah kabupaten Kaur)
- $\quad$ Suku Pasemah (menempati sebagian kecil wilayah di beberapa kabupaten di Provinsi Bengkulu)

Suku Melayu-Bengkulu (menempati wilayah kotamadya Bengkulu)

Dari sembilan suku / bahasa daerah di atas, bahasa daerah yang satu dengan bahasa daerah yang lainnya ada kesamaan (kemiripan dari segi bunyi dan makna). M isal nya kata abu (dalam bahasa Muko-muko), abaw, (bahasa rejang) , abu (Bahasa Lembak), abu (bahasa Pasemah), abu (bahasa Enggano), abu (bahasa Serawai), abu (bahasa Pekal), habu (bahasa Mulak- Bintuhan) dan abu (bahasa MelayuBengkulu) yang memiliki makna abu. Dengan demikian, ada dugaan bahwa bahasa antara satu bahasa dengan bahasa yang lainnya mempunyai unsur kekerabatan. Hal ini menarik diteliti dengan menggunakan ilmu Linguistik Historis, dan Komparatif (LHK). Tujuan dari Linguistik Historis Kompratif menurut Keraf $(1996 ; 23)$ yakni:

1. Mempersoalkan bahasa-bahasa yang serumpun dengan mengadakan perbandingan-perbandingan terhadap unsurunsur yang menunjukan kekerabatannya.

2. Mengadakan rekonstruksi bahasa-bahasa yang ada saat ini dengan bahasa purba atau bahasa yang menurun pada bahasa yang kontemporer.

3. Mengadakan pengelompokan bahasabahasa yang termasuk dalam bahasa satu rumpun.

4. Menemukan pusat-pusat penyebaran bahasa proto dan bahasa kerabat serta menentukan gerak migrasi yang pernah terjadi.

Salah satu kajian LHK adalah Leksikostatistik. Menurut Keraf (1996;121) leksikostatistik adalah suatu teknik dalam pengelompokan data menggunakan peneropongan kata-kata secara statistik, untuk kemudian berusaha menempatkan pengelompokan itu berdasarkan persamaan dan perbedaan suatu 
bahasa dengan bahasa yang Iain. Kajian Leksikostatistik pada bahasa-bahasa yang terdapat di Provinsi Bengkulu khususnya kajian yang telah terpublikasi masih sangat jarang dilakukan, oleh karena itu penelitian tertarik untuk melakukan penelitian ini untuk memberikan informasi tentang unsur kekerabatan ketiga bahasa tersebut.

\section{TEORI DAN METODE}

Untuk mengetahui hubungan kekerabatan bahasa Rejang, Serawai dan Pasemah maka peneliti menggunakan metode kuantitatif dengan teknik leksikostatistik. Data penelitian diperoleh dari hasil wawancara kepada penutur asli tiap bahasa dan informasi dari kamus Bahasa Rejang yang disusun oleh Syahril Chili dkk pada tahun 2010. Secara lebih rinci penelitian dilakukan melalui langkahlangkah sebagai berikut (Keraf; 1986:35)

1. Mengumpulkan kata-kata kosa kata dasar

2. Mentapkan pasangan kosa kata kerabat.

3. $\mathrm{t}=\frac{\log C}{2 \log r}$

Menghitung Iama waktu pisah dengan rumus:

$$
\mathrm{t}=\frac{\log C}{2 \log r}
$$

$\mathrm{t}=$ Iama waktu pisah dalam satuan ribuan tahun.

$\mathrm{C}=$ Persentase kata-kata sekerabat dari dua bahasa.

$r=$ Indeks retensi 0,805 .

4. Menghitung lama waktu pisah setelah dihitung jangka kesalahan.

Berikut cara menghitung jangka kesal ahan standar:

$$
S=\sqrt{\frac{C(1-C)}{N}}
$$

$\mathrm{S}=$ Kesalahan standad dalam persentase kekrabatan.

$\mathrm{C}=$ Persentase kata-kata sekerabat dari dua bahasa.

$n=$ Jumlah kata yang dibandingkan.

Menghitung lama waktu II dengan rumus sebagai berikut.

$$
=\frac{\log \left(\mathrm{C}+\frac{\sqrt{\mathrm{C}(1-\mathrm{C}}}{\mathrm{N}}\right)}{2 \operatorname{lng} r}
$$

5. Menghitung jangka kesalahan

Untuk menghitung jangka kesal ahan yang sebenarnya digunakan rumus t- t1

Keterangan:

$\mathrm{t}=$ Lama waktu dalam ribuan tahun

t1 = Lama waktu hitung 2 setelah menghitung jangka kesalahan

6. Menghitung berpisahnya bahasa dari bahasa purbanya.

7. Mengkalasifikasikan bahasa. Klasifikasi bahasa yang dirumuskan oleh Swadesh dapat dilihat pada tabel berikut:

\begin{tabular}{|c|c|c|}
\hline Tingkatan bahasa & Waktu pisah dalam abad & Persentase bahas kerabat \\
\hline Bahasa & $0-5$ & $100-81$ \\
\hline Keluarga & $5-25$ & $81-36$ \\
\hline Rumpun & $25-50$ & $36-12$ \\
\hline Mikrofilum & $50-75$ & $12-4$ \\
\hline Misofilum & $75-100$ & $4-1$ \\
\hline Makrofilum & $100-$ ke atas & $1-$ kurang dari $1 \%$ \\
\hline
\end{tabular}

\section{HASIL DAN PEMBAHASAN}

Mom Swadess dalam Keraf $(1996 ; 139)$ menyusun kosa kata dasar yang dianggap universal untuk menentukan usia bahasa-bahasa kerabat. Daftar kosa kata yang digunakan disebut dengan istilah Gloss. Berikut daftar Gloss dan penggunaannya dalam Bahasa Serawai, Rejang, Pasemah: 


\begin{tabular}{|c|c|c|c|c|}
\hline No & Gloss & SERAWAI & $\begin{array}{l}\text { REJANG } \\
\end{array}$ & PASEMAH \\
\hline 1 & Abu & [abu] & [abaw] & [abu] \\
\hline 2 & Air & [ayi?a] & [bioywa?] & [ayi?] \\
\hline 3 & Akar & [akaR] & [balet] & [akaRe] \\
\hline 4 & Aku & [aku] & [uku] & $\overline{\text { [aku] }}$ \\
\hline 5 & Alir & [a ñut] & [monot] & [alir] \\
\hline 6 & Ambil & [ambiak] & [mok] & [ambik] \\
\hline 7 & Anak & [ana?] & [anok] & [ana?] \\
\hline 8 & Angin & [ayin] & [aygin] & [anin] \\
\hline 9 & Anjing & [anjin] & [kuyuk] & [anjin] \\
\hline 10 & Apa & {$[$ nap $\sigma]$} & [jano] & [napə] \\
\hline 11 & Api & $\begin{array}{l}\text { [api] } \\
\end{array}$ & [opoy] & $\overline{\text { [api] }}$ \\
\hline 12 & Apung & [ngapun] & [napuy] & $\overline{\text { [gapun] }}$ \\
\hline 13 & Asap & [asap] & [asǑp] & [asap] \\
\hline 14 & Atas & [atas] & [das] & [pucuk] \\
\hline 15 & Awan & [awan] & [əmbun] & [awan] \\
\hline 16 & Ayam & [ayam] & [monok] & [ayam] \\
\hline 17 & Baik & \begin{tabular}{|l} 
[ilu?a] \\
\end{tabular} & [baik] & [bai?] \\
\hline 18 & Bakar & [yilap] & [nembem] & 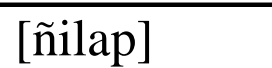 \\
\hline 19 & Balik & [bali?] & [bele?] & [bali?] \\
\hline 20 & Bambu & [bambu] & [bulua?] & [buluh] \\
\hline 21 & Bangun & $\begin{array}{l}\text { [bangun] } \\
\end{array}$ & [tlongon] & [bangun] \\
\hline 22 & Banyak & [baña?] & [daw] & [baña?] \\
\hline 23 & Bapak & \{ba?] & [bak] & $\{\mathrm{ba} ?]$ \\
\hline 24 & Baru & $\begin{array}{l}\text { [mule] } \\
\end{array}$ & [blow] & [baRhu] \\
\hline 25 & Basah & [basa] & [cŐa?] & [basa] \\
\hline 26 & Batu & [batu] & [butəu] & [batu] \\
\hline 27 & Bawah & [bawah] & [bea?] & [bawah] \\
\hline 28 & Benar & [bənar] & [bnəa] & [bənaRə] \\
\hline 29 & Bengkak & [bənka?] & [bako?] & [bənka?] \\
\hline 30 & Benih & [bəniah] & [bənia?] & [bðnih] \\
\hline 31 & Berani & [beghani] & [binai] & [beghani] \\
\hline 32 & Beras & [beghas] & [blas] & [beghhas] \\
\hline 33 & Berhenti & [brenti] & [brenti] & [mandak] \\
\hline
\end{tabular}




\begin{tabular}{|c|c|c|c|c|}
\hline 34 & Binatang & [binatan] & [binatang] & \begin{tabular}{|l} 
[binatan] \\
\end{tabular} \\
\hline 35 & Buah & [buah] & [bua?] & [buah] \\
\hline 36 & Bulan & [bulan] & [bulən] & [bulan] \\
\hline 37 & Bulu & [bulu] & [bulau] & \begin{tabular}{|l} 
[bulu] \\
\end{tabular} \\
\hline 38 & Bunga & [bungau] & [bungai] & \begin{tabular}{|l} 
[bunə] \\
\end{tabular} \\
\hline 39 & Bunuh & [bunuah] & [nunua?] & \begin{tabular}{|l} 
[bunuh] \\
\end{tabular} \\
\hline 40 & Cacing & [gðlan] & [gəlon] & [gðlan] \\
\hline 41 & Cium & [cium] & [semnyum] & \begin{tabular}{|l} 
[cium] \\
\end{tabular} \\
\hline 42 & Cuci & [basuah] & [nәрар] & \begin{tabular}{|l} 
[basuah] \\
\end{tabular} \\
\hline 43 & Daging & [dagin] & [dagin] & \begin{tabular}{|l|} 
[dagin] \\
\end{tabular} \\
\hline 44 & Danau & [danaw] & [danəu] & \begin{tabular}{|l} 
[danaw] \\
\end{tabular} \\
\hline 45 & Darah & [daRah] & [dalea?] & \begin{tabular}{|l} 
[daRgah] \\
\end{tabular} \\
\hline 46 & Datang & [datan] & $\begin{array}{l}\text { [datang] } \\
\end{array}$ & \begin{tabular}{|l|} 
[datan] \\
\end{tabular} \\
\hline 47 & Daun & [daun] & [daun] & [daun] \\
\hline 48 & Dekat & [dəkat] & [paa?] & \begin{tabular}{|l} 
[para?] \\
\end{tabular} \\
\hline 49 & Delapan & [delapan] & [delapon] & \begin{tabular}{|l} 
[lapan] \\
\end{tabular} \\
\hline 50 & Dengan & [dəyan] & [yen] & \begin{tabular}{|l} 
[dəyan] \\
\end{tabular} \\
\hline 51 & Dengar & [dənar] & \{temiu?] & \begin{tabular}{|l} 
[dəyar] \\
\end{tabular} \\
\hline 52 & Dorong & [tula?] & [dmoron] & \begin{tabular}{|l} 
[undu] \\
\end{tabular} \\
\hline 54 & Dua & [duaw] & [duai] & \begin{tabular}{|l} 
[due] \\
\end{tabular} \\
\hline 55 & Duduk & [dudu?a] & [temOัt] & [dudu?] \\
\hline 56 & Ekor & [ikoa] & [ikuR] & [ikoa] \\
\hline 57 & Empat & [ðmpat] & [pat] & [ðmpat] \\
\hline 58 & Enau & $\begin{array}{l}\text { naw] } \\
\end{array}$ & [naw] & [enau] \\
\hline 59 & Engkau & [kaw] & {$[\mathrm{kǑ}]$} & [kabah] \\
\hline 60 & Gali & [najah] & [gmali] & [gali] \\
\hline 61 & Gantung & [gatung] & [gatuy] & \begin{tabular}{|l} 
[gantung] \\
\end{tabular} \\
\hline 62 & Garam & [garam] & [garam] & \begin{tabular}{|l} 
[gaRam] \\
\end{tabular} \\
\hline 63 & Garuk & [gahut] & [gmarut] & \begin{tabular}{|l} 
[gaRhut] \\
\end{tabular} \\
\hline 64 & Gemuk & [gemuak] & [gəmu?] & \begin{tabular}{|l|} 
[bunta?] \\
\end{tabular} \\
\hline 65 & Gigi & [gigi] & [әреn] & \begin{tabular}{|l} 
[gigi] \\
\end{tabular} \\
\hline 66 & Gigit & [gigit] & [nonǑt] & \begin{tabular}{|l} 
[gigit] \\
\end{tabular} \\
\hline 67 & Gosok & [nabiah] & [gənOัsǑ?] & \begin{tabular}{|l} 
[gesik] \\
\end{tabular} \\
\hline
\end{tabular}




\begin{tabular}{|c|c|c|c|c|}
\hline 67 & Gosok & [nabiah] & [gənOัsǑ?] & [gesik] \\
\hline 68 & Gunung & $\begin{array}{l}\text { [gunuy] } \\
\end{array}$ & $\begin{array}{l}\text { [gunun] } \\
\end{array}$ & $\begin{array}{l}\text { [gunuy] } \\
\end{array}$ \\
\hline 69 & Hantam & [tinju] & [nomoah] & [bəgoco] \\
\hline 70 & Hapus & [apus] & [apus] & [apus] \\
\hline 71 & Hati & [ati] & [atəi\} & [ati] \\
\hline 72 & Hidung & [idup] & [yuy] & [iduy] \\
\hline 73 & Hidup & [idup] & [idup] & [idup] \\
\hline 74 & Hijau & [ijau] & [ijo] & [ijan] \\
\hline 75 & Hisap & [isap] & [nesep] & [isap] \\
\hline 76 & Hitam & [itam] & [mləu] & [itam] \\
\hline 77 & Hitung & [itun] & {$[$ mitun $\}$} & [bərhitun] \\
\hline 78 & Hutan & [utan] & [utan] & [Rhimbə] \\
\hline 79 & Ibu & [ma?] & [ma?] & [ənduy] \\
\hline 80 & Ikan & [ikan] & [kan] & [ikan] \\
\hline 81 & Ikat & [kəbat] & [eket] & [kəbat] \\
\hline 82 & Ingat & [ingat] & [tmingət] & [igat] \\
\hline 83 & Istri & [bini] & [ngənyan] & [bini] \\
\hline 84 & Jagung & [jagung] & [jagung] & [jagung] \\
\hline 85 & Jahit & [jait] & [ndet] & [jait] \\
\hline 86 & Jalan & [jalan] & [jalan] & [jalan] \\
\hline 87 & Jantung & [jantuy] & [jatun] & [jantuy] \\
\hline 88 & Kabut & [kabut] & [kabut] & [kabut] \\
\hline 89 & Kaki & [kətin] & [kekea] & [kətin] \\
\hline 90 & Kalau & [kalu] & [amən] & [kalu] \\
\hline 91 & Kami & [kami] & [keme] & [kami] \\
\hline 92 & Kamu & [kamu] & [kumu] & [kamu] \\
\hline 93 & Kanan & [kanan] & [kanan] & [kanan] \\
\hline 94 & Kapak & [kapa?] & [kapǑ?] & [kapa?] \\
\hline 95 & Karena & [kerno] & [korno] & [kerno] \\
\hline 96 & Kasar & [kasar] & [kasaR] & [kasar] \\
\hline 97 & Kata & [kato] & [nadəa?] & [katə] \\
\hline 98 & Kecil & [kəcia?] & [titi?] & [kəci?] \\
\hline 99 & Kelahi & [bəlagau] & [blangai] & [bəlagə] \\
\hline 100 & Kepala & [pala?] & [ulaw] & [pala?] \\
\hline 101 & Kering & [kəriy] & [ke in] & [kərhin] \\
\hline
\end{tabular}




\begin{tabular}{|c|c|c|c|c|}
\hline 102 & Keringat & [kəringat] & [eten] & [peluh] \\
\hline 103 & Kiri & [kidau] & [kidəu] & [kidaw] \\
\hline 104 & Kotor & [kumuah] & [gumŎ?] & [kulat] \\
\hline 105 & Kuku & [kuku] & [slǑn] & [kuku] \\
\hline 106 & Kulit & [kuliat] & [baba?] & [kulit] \\
\hline 107 & Kuning & [kunin] & [kunin] & [kunin] \\
\hline 108 & Kurus & [kuRus] & [kuRus] & [kuhus] \\
\hline 109 & Kutu & [kutu] & [kutaw] & [kutu] \\
\hline 110 & Ladang & [umau] & [dumai] & [kebun] \\
\hline 111 & Lain & [lain] & [luyən] & [lain] \\
\hline 112 & Lalat & [lalat] & [lalət] & [lalat] \\
\hline 113 & Lambat & [lambat] & [lambat] & [lame] \\
\hline 114 & Langit & [lanit] & [loyet] & [layet] \\
\hline 115 & Laut & [laut] & [laut] & [laut] \\
\hline 116 & Lebar & [libaRg] & [libəa] & [libao] \\
\hline 117 & Leher & [liyaR] & [kagən] & [liaə] \\
\hline 118 & Lelaki & [lanay] & [smanəi] & [lanay] \\
\hline 119 & Lempar & [gutu?] & [nəlu?] & [lacip] \\
\hline 120 & Lepas & [lepas] & [mləpas] & [pacul] \\
\hline 121 & Licin & [liut] & [liut] & [liut] \\
\hline 122 & Lidah & [lidah] & [inǑa] & [lidah] \\
\hline 123 & Lima & [limau] & [ləmŎ] & [lime] \\
\hline 124 & Mabuk & [mabua?] & [mabu?] & [mabuk] \\
\hline 125 & Main & [busi?] & [main] & [tanday] \\
\hline 126 & Makan & [makan] & [mbu?] & [makan] \\
\hline 127 & Malam & [malam] & [maləm] & [malam] \\
\hline 128 & Matahari & [matoaRi] & [matəy bilai] & [matahari] \\
\hline 129 & Mentimun & [timun] & [ləpay] & [lepang] \\
\hline 130 & Merah & [abay] & [miləa?] & [abay] \\
\hline 131 & Mereka & [kapo] & [udi] & [kamu] \\
\hline 132 & Naik & [naik] & [kəmnə?] & [naik] \\
\hline 133 & Napas & [ñyawo] & [napas] & [napas] \\
\hline 134 & \begin{tabular}{|l|} 
Nyamuk \\
\end{tabular} & $\begin{array}{l}\text { [agas] } \\
\text { ags }\end{array}$ & [nyŎmok] & $\begin{array}{l}\text { [agas] } \\
\end{array}$ \\
\hline 135 & \begin{tabular}{|l} 
Nyanyi \\
\end{tabular} & [ñyañi] & [ก̃añi] & [ก̃añi] \\
\hline 136 & Nyiur & [nyiuagh] & [nyŎa] & [nio] \\
\hline 137 & Orang & [jomo] & [tun] & [jəmə] \\
\hline 138 & Padi & [padi] & [pOัi] & [padi] \\
\hline 139 & Pahit & [pait] & [pet] & [pait] \\
\hline
\end{tabular}




\begin{tabular}{|c|c|c|c|c|}
\hline 140 & Panas & [ayat] & [panəs] & [angat] \\
\hline 141 & Pandan & [pandan] & [pandan] & [pandan] \\
\hline 142 & Panggil & [panggil] & [mədəu] & [pantau] \\
\hline 143 & Panjang & [panjan] & [panjay] & [panjay] \\
\hline 144 & Pasir & [buyin] & [bnəi] & [buyin] \\
\hline 145 & Pegang & [nəca?] & [mgǑng] & [kəca?] \\
\hline 146 & Pendek & [panda?] & [pendŎ?] & [pənda?] \\
\hline 148 & Penyu & [penyu] & [penyu] & [labi] \\
\hline 149 & Perahu & [perahu] & [prahu] & [perau] \\
\hline 150 & Perempuan & [tinə] & [slawəi] & [botinə] \\
\hline 151 & Pergi & [pergi] & [lalau] & [pegi] \\
\hline 152 & Perisai & [prisai] & [prisai] & [prisai] \\
\hline 153 & Perut & [pəRhut] & [tenəi] & [pəRhut] \\
\hline 147 & Piker & [pikiR] & [nekeR] & [pikiR] \\
\hline 154 & Pintar & [pintaR] & [pitaR] & [pintaR $]$ \\
\hline 155 & Pisang & [pisang] & [pisay] & [pisang] \\
\hline 156 & Putus & [putus] & [putus] & [putus] \\
\hline 157 & Rambut & [gumba?] & [bu?] & [gumba?] \\
\hline 158 & Ringan & [ringan] & [leyan] & [ampung] \\
\hline 159 & Rumah & [rumah] & [uməa?] & [ghuma] \\
\hline 160 & Rumput & {$[\mathrm{kud}]$} & [dukut] & [humpud] \\
\hline 161 & Sakit & [sakit] & [gis] & [bidapan] \\
\hline 163 & Salah & $\begin{array}{l}\text { [salah] } \\
\text { nal }\end{array}$ & [salea?] & [salah] \\
\hline 164 & Salam & [salam] & [salam & [salam] \\
\hline 165 & Satu & [satu] & [dOั] & [sute?] \\
\hline 166 & Sayap & [sayap] & [sayəp] & [sayap] \\
\hline 167 & Sayur & [sayuGh] & [sayuR] & [taghu?] \\
\hline 168 & Sedikit & [dikit] & [didi?] & [dikit] \\
\hline 169 & Selam & [selam] & [səmləm] & [selam] \\
\hline 170 & Sembilan & [sembilan] & [sembilan] & [sembilan] \\
\hline 162 & Sempit & [sOmpit] & [səpit] & [sӘmpit] \\
\hline 171 & Sepuluh & [sepulua] & [pulua?] & [sepulu] \\
\hline 172 & Siang & [sian] & [luen] & [sian] \\
\hline 173 & Siapa & [siapo] & [api] & [sapə] \\
\hline 174 & Tadi & [tadi] & [nanǑ] & [tadi] \\
\hline 175 & Tahu & [tau] & [namən] & [paca?] \\
\hline 176 & Tahun & [taun] & {$[\operatorname{taun}\}$} & [taun] \\
\hline
\end{tabular}




\begin{tabular}{|c|c|c|c|c|}
\hline 177 & Tajam & [tajam] & [tajəm] & [landap] \\
\hline 178 & Takut & [takut] & [sabən] & [geme] \\
\hline 179 & Tanam & [nanam] & [tmanəm] & [nanam] \\
\hline 180 & Tanduk & tandu?] & [tmandu?] & tandu?] \\
\hline 181 & Tebal & [tӘbal] & [tebǑa] & [tӘbal] \\
\hline 182 & Tebu & [tebu] & {$[$ təbau $\}$} & $\begin{array}{l}\text { [tebu] } \\
\end{array}$ \\
\hline 183 & Tempa & [nempa] & [tməpa] & [nempa] \\
\hline 184 & Terima & [terimau] & [təmimOั] & [terime] \\
\hline 185 & Tidur & [tidu?] & [tiduwa] & [tidu?] \\
\hline 186 & Tiga & [tigo] & [tlaw] & [tigə] \\
\hline 187 & Tikam & [tujah] & [tujua?] & [nujah] \\
\hline 189 & Tikus & [tikus] & [tikus\} & [tikus] \\
\hline 188 & Tipis & [tipis] & [tipis] & [nipis] \\
\hline 190 & Tiup & $\begin{array}{l}\text { niup] } \\
\end{array}$ & [tmiup] & $\begin{array}{l}\text { tiup] } \\
\end{array}$ \\
\hline 191 & Tongkat & [tunkat] & [tokot & [tonkat] \\
\hline 192 & Tua & [tuwo] & [tuai] & [tuə] \\
\hline 193 & Tulang & [tulan & [tlan] & [tulan] \\
\hline 194 & Tumpul & [tumpul] & [tŎpoa] & [tumpul] \\
\hline 195 & Turun & [tuGhun] & [tu?un] & $\begin{array}{l}\text { [tuGhun] } \\
\end{array}$ \\
\hline 196 & Tusuk & [tujah] & [tmusu?] & [cucu?] \\
\hline 197 & $\overline{\mathrm{Ubi}}$ & [ubi\} & [uabai] & $\begin{array}{l}\text { [ubi] } \\
\end{array}$ \\
\hline 198 & Udang & [udang] & $\begin{array}{l}\text { [udang] } \\
\end{array}$ & $\begin{array}{l}\text { [udang] } \\
\end{array}$ \\
\hline 199 & Ular & [ulaR] & $\begin{array}{l}\text { [dung] } \\
\end{array}$ & [ulagh] \\
\hline 200 & Usus & [usus] & [usus] & [usus] \\
\hline
\end{tabular}


Setelah diketahuinya gloss dan penggunaannya pada Bahasa Serawai Rejang dan Pasemah maka langkah selanjutnya adalah penetapan kata kerabat antara dua bahasa terlebih dahulu. Sebuah pasangan kata akan dinyatakan sebagai kata kerabatjika memenuhi salah satu ketentuan berikut:

1. Pasangan kata identik.

2. Psangan kata memiliki korespodensi fonemis.

3. Kemiripan secara fonetis.

4. Hanya satu fonem yang berbeda.

Pasangan kata yang dianggap mempunyai unsur kerabat diberi tanda ( +) sedangkan kata yang tidak mempunyai unsur kerabat diberi tanda ( - ). Berdasarkan tabel penetapan kata kerbat tersebut maka langkah selanjutnya adalah menghitung persentase kata kerabat dengan menggunakan rumus

$\mathrm{C}=\frac{\text { Jumlah kata sekerabat }}{\text { Jumalah kosa kata dasar yang dapat dibandingkan }} \times 100$

Berdasarkan rumus diatas maka dapat diketahui persentase kata kerabat bahasa:

Serawai-Rejang $=166 / 199 \times 100=58,29 \%$ di bulatkan menjadi $58 \%$

Serawai-Pasemah $=167 / 199 \times 100=83,9 \%$ di

bulatkan menjadi $84 \%$

Rejang-Pasemah $=113 / 199 \times 100=56,7 \%$ di

bulatkan menjadi $57 \%$

Setelah mengetahui persentase kata kerabat, langkah selanjutnya adalah menghitung waktu pisah antara bahasa tersebut. Bahasa Serawai-Rejang C $=58 \%$

$$
\begin{aligned}
& \mathrm{t}=\frac{\log C}{2 \log r} \\
& \mathrm{t}=\frac{\log 0,58}{2 \log 0,805}= \\
& \mathrm{t}=\frac{0,545}{0,434} \\
& \mathrm{t}=1,255 \times 1000=1255 \text { tahun }
\end{aligned}
$$

Jangka kesalahan standar

$$
\begin{aligned}
& \mathbf{S}=\sqrt{\frac{\mathbf{C}(\mathbf{1}-\mathbf{C})}{\mathbf{N}}} \\
& S=\sqrt{\frac{0,58(1-0,58)}{199}} \\
& S=\sqrt{\frac{0,58(0,42)}{199}} \\
& S=\sqrt{\frac{0,244)}{199}} \\
& S=\sqrt{0,001} \\
& S=0,035
\end{aligned}
$$

Menghitung waktu pisah 2

$$
\mathrm{t}_{1}=\frac{\log \left(\mathrm{C}+\sqrt{\frac{\mathrm{C}(1-\mathrm{C}}{\mathrm{N}}}\right)}{2 \log r}
$$$$
\mathrm{t}_{1}=\frac{\log 0,58+0,035}{0,434}
$$$$
\mathrm{t}_{1}=\frac{\log 0,615}{0,434}
$$$$
\mathrm{t}_{1}=\frac{0,494}{0,434}
$$$$
\mathrm{t}_{1}=1,138 \times 1000=1138 \text { tahun }
$$

Menghitung jangka kesalahan

$$
t-t_{1}
$$

$1255-1138=117$ Tahun

Jadi berpisahnya bahasa Serawai dan bahasa Rejang terjadi antara 1327 - 1138 tahun yang lalu, yaitu sekitar tahun $690 \mathrm{M}$ sampai tahun 877 M (di hitung dari tahun 2017). Bahasa Serawai-Pasemah C = $84 \%$

$$
\mathrm{t}=\frac{\log C}{2 \log r}
$$




$$
\begin{aligned}
\mathrm{t} & =\frac{\log 0,84}{2 \log 0,805}= \\
\mathrm{t} & =\frac{0,174}{0,434} \\
\mathrm{t} & =0,401 \times 1000=401 \text { tahun } \\
\mathbf{S} & =\sqrt{\frac{\mathbf{C}(\mathbf{1}-\mathbf{C})}{\mathbf{N}}} \\
\mathrm{S} & =\sqrt{\frac{0,84(1-0,84)}{199}} \\
\mathrm{~S} & =\sqrt{\frac{0,84(0,16)}{199}} \\
\mathrm{~S} & =\sqrt{\frac{0,1344)}{199}} \\
\mathrm{~S} & =\sqrt{0,007} \\
\mathrm{~S} & =0,025
\end{aligned}
$$

Menghitung Lama Waktu Pisah 2

$$
\mathrm{t}_{1}=\frac{\log \left(\mathrm{C}+\sqrt{\frac{\mathrm{C}(1-\mathrm{C}}{\mathrm{N}}}\right)}{2 \log r}
$$

$\mathrm{t}_{1}=\frac{\log 0,84+0,025}{0,434}$

$\mathrm{t}_{1}=\frac{\log 0,865}{0,434}$

$\mathrm{t}_{1}=\frac{0,151}{0,434}$

$\mathrm{t}_{1}=0,347 \times 1000=347$ tahun

Menghitung jangka kesalahan

$$
t-t_{1}
$$

$401-347=54$ Tahun

Jadi berpisahnya bahasa Serawai dan bahasa Rejang terjadi antara 1327 - 1138 tahun yang lalu, yaitu sekitar tahun 690 M sampai tahun $877 \mathrm{M}$ (di hitung dari tahun 2017). Bahasa Serawai-Pasemah C = $84 \%$

$$
\begin{aligned}
& \mathrm{t}=\frac{\log C}{2 \log r} \\
& \mathrm{t}=\frac{\log 0,57}{2 \log 0,805}= \\
& \mathrm{t}=\frac{0,562}{0,434}
\end{aligned}
$$

$\mathrm{t}=1,295 \times 1000=1295$ tahun

$S=\sqrt{\frac{C(1-C)}{N}}$

$S=\sqrt{\frac{0,57(1-0,57)}{199}}$

$S=\sqrt{\frac{0,57(0,43)}{199}}$

$S=\sqrt{\frac{0,245)}{199}}$

$\mathrm{S}=\sqrt{0,001}$

$\mathrm{S}=0,035$

$\mathrm{t}_{1}=\frac{\log \left(\mathrm{C}+\sqrt{\frac{\mathrm{C}(1-\mathrm{C}}{\mathrm{N}}}\right)}{2 \log r}$

$\mathrm{t}_{1}=\frac{\log 0,57+0,035}{0,434}$

$\mathrm{t}_{1}=\frac{\log 0,605}{0,434}$

$\mathrm{t}_{1}=\frac{0,511}{0,434}$

$\mathrm{t}_{1}=1,118 \times 1000=1.188$ tahun

$t-t_{1}$ 
$1295-1188=107$ Tahun

Jadi berpisahnya Bahasa Rejang dan Bahasa Pasemah terjadi antara 1402 - 1188 tahun yang lalu, yaitu sekitar tahun $615 \mathrm{M}$ sampai tahun 829 M (di hitung dari tahun 2017). Klasifikasi Bahasa:

\begin{tabular}{|c|c|c|}
\hline Tingkatan bahasa & Waktu pisah dalam abad & Persentase bahas kerabat \\
\hline Bahasa & $0-5$ & $100-81$ \\
\hline Keluarga & $5-25$ & $81-36$ \\
\hline Rumpun & $25-50$ & $36-12$ \\
\hline Mikrofilum & $50-75$ & $12-4$ \\
\hline Misofilum & $75-100$ & $4-1$ \\
\hline Makrofilum & $100-$ ke atas & $1-$ kurang dari $1 \%$ \\
\hline
\end{tabular}

Jika dilihat waktu pisah anatara ke-3 bahasa tersebut dimana waktu pisah.

Serawai-Rejang: 1327 - 1138 tahun yang Ialu

Serawai-Pasemah: antara 455 - 347 tahun yang Ialu

Rejang-Pasemah: antara 1402 - 1188 tahun yang lalu

Maka dapat kita simpulkan bahwa ketiga bahasa tersebut masih dalam satu bahasa karena waktu pisah masih berkisar antara 0-5 abad. Jika kita lihat persentase kata kerabat dapat kita ketahui,

$\begin{array}{ll}\text { Serawai-Rejang } & : 58 \% \\ \text { Serawai-Pasemah } & : 84 \% \\ \text { Rejang-Pasemah } & : 57 \%\end{array}$

Maka dapat kita simpulkan bahawa bahasa Serawai-Rejang dan Rejang-Pasemah merupakan satu bahasa (language), sedangkan bahasa Serawai-Pasemah merupakan Keluarga (family) karena persentase kata kerabat $84 \%$.

\section{PEN UTUP}

\section{Simpulan}

Berdasarkan hasil pembahasan yang telah dilakukan terhadap bahasa Rejang, Serawai dan Pasemah maka dapat disimpulkan
1. Berpisahnya bahasa Serawai dan bahasa Rejang terjadi antara 1327 - 1138 tahun yang lalu, yaitu sekitar tahun $690 \mathrm{M}$ sampai tahun $879 \mathrm{M}$ (di hitung dari tahun 2017).

2. Berpisahnya Bahasa Serawai dan Bahasa Pasemah terjadi antara 455 - 347 tahun yang Ialu, yaitu sekitar tahun 1562 M sampai tahun $1670 \mathrm{M}$ (di hitung dari tahun 2017).

3. Berpisahnya Bahasa Rejang dan Bahasa Pasemah terjadi antara 1402 - 1188 tahun yang Ialu, yaitu sekitar tahun $615 \mathrm{M}$ sampai tahun $829 \mathrm{M}$ (di hitung dari tahun 2017).

Jika dilihat waktu pisah antara ke-3 bahasa tersebut dimana waktu pisah:

Serawai-Rejang: antara 1327 - 1138 tahun yang Ialu

Serawai-Pasemah: antara 455 - 347 tahun yang Ialu

Rejang-Pasemah: antara 1402 - 1188 tahun yang Ialu

Maka dapat kita simpulkan bahwa ketiga bahasa tersebut masih dalam satu bahasa karena waktu pisah masih berkisar antara 0-5 abad. Namun jika kita lihat persentase kata kerabat dapat kita ketahui:

$\begin{array}{ll}\text { Serawai-Rejang } & : 58 \% \\ \text { Serawai-Pasemah } & : 84 \% \\ \text { Rejang-Pasemah } & : 57 \%\end{array}$

Maka dapat kita simpulkan bahawa bahasa Serawai-Rejang dan Rejang- Pasemah merupakan satu bahasa (language), sedangkan bahasa Serawai-Pasemah merupakan Keluarga (family) karena persentase kata kerabat $84 \%$.

\section{Saran}

Indonesia merupakan Bangsa yang kaya akan bahasa daerah. Data pada situs wikipedia, pada tahun 2010 BPS telah mencatat ada 1158 bahasa daerah yang tersebar di berbagai wilayah di Indonesia diantaranya bahasa 
Rejang, Serawai dan Pasemah yang banyak digunakan di Provinsi Bengkulu. Hasil Penelitian menunjukan bahwa bahasa tersebut masih memiliki unsur kekerabatan. Bahasa-bahasa tesebut harus terus dilestarikan, jika tidak sangat berpotensi bahasa-bahasa daerah di Indonesia perlahan akan mengalami kepunahan. Pelestarian bahasa tersebut harus dimulai dengan menanamkan rasa kecintaan terhadap bahasa yang dimulai dari diri sendiri.

\section{DAFTAR PUSTAKA}

Keraf, Gorys. 1996. Linguisik Bandingan Historis. Jakarta: Gramedia.

Chili, Syahril. Rahimullah. 2010. Kamus Lengkap Indonesia-Rejang RejangIndonesia. Jakarta: Fakultas Hukum Universitas Satya Gama.

https:/ / id.wikipedia.org/ wiki/ Bengkulu. 7 Januari 2017 Pukul 19.30. 